\title{
PENERAPAN MANAJEMEN KESELAMATAN DAN KESEHATAN \\ KERJA DI RUMAH SAKIT
}

\author{
Fara Diba Salsabila Harahap
}

\section{Email : salsabilaharahapfaradiba@gmail.com}

\section{Latar Belakang}

Manajemen

perencanaan,

adalah proses

pengorganisasian,

pengarahan dan pengawasan usaha para anggota organisasi dan pengguanaan sumber daya organisasi lainnya agar mencapai tujuan organisasi yang telah ditetapkan.

Keselamatan kerja secara filosofi diartikan sebagai suatu pemikiran dan upaya untuk menjamin keutuhan dan kesempurnaan baik jasmaniah maupun rohaniah tenaga kerja pada khususnya dan manusia pada umumnya serta hasil budaya dan karyanya. Kesehatan kerja merupakan suatu kondisi yang bebas dari gangguan secara fisik dan psikis yang disebabkan oleh lingkungan kerja.

Rumah sakit merupakan salah satu mata rantai didalam pemberian pelayanan kesehatan serta suatu organisasi dengan sistem terbuka dan selalu berinteraksi dengan lingkungannya untuk mencapai suatu keseimbangan yang dinamis mempunyai fungsi utama melayani masyarakat yang membutuhkan pelayanan kesehatan serta sebagai tempat penelitian berdasarkan surat keputusan. Dalam pemberian pelayanan kesehatan yang optimal di rumah sakit diperlukan sumber daya yang berkualitas. Dengan menggunakan sumber daya yang ada diharapkan rumah sakit dapat menghasilkan suatu output yang maksimal berupa jasa untuk meningkatkan mutu pelayanan. Untuk masalah- masalah tersebut haruslah disadari bahwa keberhasilan rumah sakit antara lain disebabkan sumber daya manusia, sehingga sumber daya manusia dipandang sebagai asset rumah sakit, bahkan merupakan investasi rumah sakit, apabila tenaga tersebut merupakan tenaga yang terampil. Keberhasilan pelayanan di rumah sakit tidak terlepas dari berbagai faktor pelayanan keperawatan yang biasa disebut dengan asuhan keperawatan.

Kecelakaan kerja merupakan kejadian yang tidak terjadi secara kebetulan, melainkan ada sebabnya. Oleh karena ada penyebabnya, sebab kecelakaan harus 
diteliti dan ditemukan, agar untuk selanjutnya dengan tindakan korektif yang ditujukan kepada penyebab itu serta dengan upaya preventif lebih lanjut kecelakaan dapat dicegah dan kecelakaan serupa tidak berulang kembali (Suma'mur, 2013).

\section{Metode}

Metode yang digunakan dalam penulisan ini yaitu menggunakan literature riview atau studi pustaka berdasarkan teks book, jurnal dan berfokus pada Penerapan Manajemen Keselamatan dan Kesehatan Kerja di Rumah Sakit. Dengan cara menganalisis, eksplorasi sumber dan kajian bebas. Adapun sumber kajian yang digunakan ialah 10 tahun terakhir.

\section{Hasil}

Hasil Data dari Massachussetts Departement of Public Health (MDPH) USA pada Maret 2012, dari 98 orang rumah sakit yang dilakukan surveilans periode Januari sampai Desember 2010, terdapat 2.947 orang pekerja rumah sakit mengalami cedera terkena benda tajam termasuk jarum suntik. Sebanyak 1.060 orang perawat, 1.078 orang tenaga dokter, 511 orang tenaga teknisi phlebotomy dan sisanya 1.119 orang tenaga pelayan pendukung lainnya (Letitia K. Davis, 2013). Dalam laporan Bureau Labor Statistics USA (2009) bahwa tingkat kejadian hilang hari kerja di rumah sakit akibat cedera terpeleset (slip), tersandung (trip) dan terjatuh (fall). Slip, Trip and Fall (STF) adalah 38,2 per 10.000 karyawan rumah sakit. Dalam aktivitas pekerjaannya, tenaga kesehatan di rumah sakit mengalami STF sering terjadi cedera yang serius hingga berakibat hari kerja hilang, produktivitas berkurang, klaim kompensasi yang mahal dan kemampuan berkurang dalam merawat pasien (NIOSH, 2010).

Di Indonesia, data mengenai Penyakit Akibat Kerja (PAK) dan Kecelakaan Kerja (KK) di sarana umum kesehatan secara umum belum tercatat dengan baik, namun menurut Departemen Kesehatan (Depkes) 2007, diketahui bahwa risiko bahaya yang dialami oleh pekerja di rumah sakit adalah infeksi HIV $(0,3 \%)$, risiko pajanan membrane mukosa (1\%), risiko pajanan kulit.

Berdasarkan data dari World Health Organization (WHO) : Dari 35 juta pekerja kesehatan 3 juta terpajan patogen darah (2 juta terpajan virus HBV, 0,9 juta terpajang virus HBC dan 170,000 terpajan virus HIV/ AIDS). Dapat terjadi : $15,000 \mathrm{HBC}, 70,000$ HBB \& 1000 kasus HIV. Lebih dari 90\% terjadi di negara berkembang.8$12 \%$ pekerja rumah sakit, sensitif terhadap lateks. Probabilitas penularan 
HIV setelah luka tusuk jarum suntik yang terkontaminasi HIV 4: 1000. Risiko penularan HBV setelah luka tusuk jarum suntik yang terkontaminasi HBV 27-37: 100. Risiko penularan HCV setelah luka tusuk jarum suntik yang mengandung $\mathrm{HCV} \quad 3 \quad-10: 100$ (Sunandar, 2017).Rumah Sakit Umum Mitra Sejatisebagai salah satu pusat rujukan pelayanan kesehatan

Dalam Memberikan pelayanan menyeluruh dibidang kesehatan secara cermat dan tepat. Dengan didukung tenaga medis yang profesional dan berkompeten dibidangnya, serta sarana dan prasarana yang modern dan lengkap dengan tarif yang terjangkau oleh masyarakat pada umumnya. Dengan memegang teguh pada prinsip sosial, Rumah Sakit terus menerus meningkatkan pelayanan kesehatan yang terbaik kepada masyarakat dan aktif berperan serta membantu pemerintah dalam upaya meningkatkan derajat kesehatan masyarakat.

\section{Pembahasan}

Era globalisasi merupakan salah satu tuntutan dari perkembangan zaman yang dimana berbagai persaingan bisnis menjadi semakin ketat dan kebutuhan manusia juga semakin meningkat, termasuk kebutuhan akan layanan kesehatan. RS Umum adalah RS yang memberikan pelayanan kesehatan pada semua bidang dan jenis penyakit. Pelayanan RS merupakan bagian yang tidak terpisah dari sistem pelayanan kesehatan pada umumnya. Dalam pemberian pelayanan kesehatan, RS diharapkan dapat memberikan pelayanan yang berkualitas.

Potensi bahaya di RS dapat disebabkan oleh faktor, yaitu:

- Biologi

- faktor kimia

- faktor ekonomi

- faktor fisik

- faktor psikososial

- bahaya mekanik, bahaya listrik dan limbah RS yang dapat mengancam jiwa dan kehidupan bagi para karyawan RS.

Pasien maupun para pengunjung yang ada dilingkungan RS yang mengakibatkan penyakit dan kecelakaan akibat kerja Kesehatan dan Keselamatan Kerja (K3) merupakan suatu upaya perlindungan kepada tenaga kerja dan orang lain yang memasuki tempat kerja terhadap bahaya dari akibat kecelakaan kerja.

Standar Kesehatan dan Keselamatan Kerja di RS (K3RS) perlu ditetapkan untuk mencegah dan mengurangi risiko kecelakaan dan penyakit akibat kerja 
di

RS. Demi terciptanya jaminan keselamatan kerja maka diperlukan pelayanan strategis yang profesional serta prosedur kerja yang tetap, tidak hanya tergantung pada peraturan-peraturan yang mengayominya dan finansial yang diberikan, melainkan banyak faktor yang harus ikut terlibat, diantaranya adalah pelaksanaan organisasi.Suatu organisasi yang berhasil dapat diukur dengan melihat pada sejauh mana organisasi tersebut dapat mencapai tujuannya. Pelaksanaan K3 di RS dapat dinilai dari kefektivitasan organisasi $\mathrm{K} 3$ tersebut (Kun dwi apriliawati,2017).

Tujuan Kesehatan dan

Keselamatan Kerja Tujuan Kesehatan dan Keselamatan Kerja menurut Mangkunegara (2002),

1. Agar setiap pegawai mendapat jaminan kesehatan dan keselamatan kerja baik secara fisik, sosial dan psikologis.

2. Agar setiap perlengkapan dan peralatan kerja digunakan sebaik - baiknya dan seektif mungkin.

3. Agar semua hasil produksi dipeliharan keamanannya.

4. Agar adanya jaminan atas pemeliharaan dan peningkatan kesehatan gizi pegawai.

Untuk mencegah dan mengurangi resiko bahaya tersebut maka perlu ditetapkan standar K3 di RS.
Perlunya pelaksanaan K3RS mengenai kebijakan pemerintah tentang $\mathrm{RS}$ di Indonesia adalah untuk meningkatkan akses, keterjangkauan, dan kualitas pelayanan kesehatan yang aman di RS. Perencanaan,pelaksanaan, monitoring,dan evaluasi K3 RS serta tindak lanjut, yang merujuk pada SK Menkes No.432/Menkes/SK/IV/2007 tentang Pedoman Manajemen K3 di RSdan OHSAS 18001 tentang Standar Sistem Manajemen K3. Sistem manajemen K3RS adalah bagian dari sistem manajemen RS.

Kebijakan K3RS di RS sesuai dengan peraturan Menteri Kesehatan dimana RS telah membuat kebijakan yang telah disusun dan diperiksa oleh direktur dan dibuat dalam bentuk tertulis. Menerapkan sistem manajemen K3RS dalam bentuk surat kerja yang telah disusun dan diperiksa oleh direktur dan dibuat dalam bentuk tertulis yang diwujudkan dalam bentuk struktural organisasi tim K3RS yang memilki tugas dan fungsi masing masing.

Pelaksanaan kesehatan dan keselamatan kerja rumah sakit tidak akan berjalan dengan baik jika direktur rumah sakit tidak menetapkan kebijakan untuk seluruh sumber daya rumah sakit. Untuk pengalokasian pendanaan telah dibuat sesuai dengan peningkatan sumber 
daya manusia dengan keahlian dibidang masing -masing dan pihak RS juga membuat pengalokasian pendanaan sesuai dengan pelaksanaan program K3 serta didalam pengalokasian anggaran dibuat dalam per 3 (tiga) bulan sekali dan dikoordinasikan kembali. Sebab suatu program K3 tidak akan terlaksanakan jika tanpa adanya pengalokasian pendanaan.

Menurut pedoman Manjamen Kesehatan dan Keselamatan Kerja ( K3 ) di rumah sakit, Depkes ( 2006 ), dalam undang - undang No 23 tahun 1992 tentang kesehatan pasal 23 dinyatakan bahwa upaya Kesehatan dan Keselamatan Kerja (K3) harus diselenggarakan disemua tempat kerja, khususnya tempat kerja yang mempunyai resiko bahaya kesehatan, mudah terjangkit penyakit atau mempunyai karyawan minimal 10 orang. Jika memperhatikan isi dari pasal tersebut, maka jelaslah bahwa rumah sakit termasuk kedalam kriteria tempat kerja dengan berbagai ancaman bahaya yang dapat menimbulkan dampak kesehatan, tidak hanya terhadap para pelaku langsung yang bekerja di rumah sakit, tapi juga terhadap pasien maupun pengunjung rumah sakit. Sehingga sudah seharusnyalah pihak pengelola rumah sakit menerapkan upaya Kesehatan dan Keselamatan Kerja ( K3 ) di Rumah Sakit.
Ada prinsipnya permasalahan timbul karena lemahnya pihak manajemen dalam menjalankan K3 dengan baik dan benar serta rendahnya tingkat kesadaran tenaga medis terhadap pentingnya pelaksanaan K3, pelatihan yang dilakukan terhadap tenaga medis juga kurang merata, tidak semua tenaga medis mendapat kesempatan yang sama untuk mengikuti pelatihan. Menurut Febriawan Ardi Nugroho ( 2014 ) Pelatihan mempunyai manfaat jangka panjang yang membantu tenaga medis memiliki tanggung jawab yang lebih besar di waktu yang akan datang. Para tenaga medis harus dilatih dan dikembangkan di bidang masing masing untuk mengurangi dan mempelajari keterampilan yang baru untuk meningkatkan kinerja mereka.

$$
\text { Proses Sistem Manajemen }
$$

Kesehatan dan Keselamatan Kerja Proses Sistem Manajemen Kesehatan dan Keselamatan Kerja menurut H. M Yani ( 2012 ), pelaksanaan Kesehatan dan Keselamatan Kerja di perusahaan sangat tergantung dari rasa tanggung jawab manajemen dan tenaga kerja terhadap tugas dan kewajiban masing- masing serta kerjasama dalam pelaksanaan K3. Proses manajemen K3 meliputi pelaksanaan fungsi-fungsi manajemen di bidang K3 yaitu fungsi perencanaan, pelaksanaan dan pengawasan. Pelaksanaan program K3 sasarannya adalah tempat kerja yang aman 
dan sehat. Untuk itu semua permasalahan yang menghambat tercapainya tujuan harus diidentifikasi, dievaluasi, dicari penyebab dasarnya untuk kemudian diupayakan cara pemecahan yang paling baik.

\section{Penutup}

Pelayanan RS merupakan bagian
yang tidak terpisah dari sistem pelayanan kesehatan pada umumnya. Dalam pemberian pelayanan kesehatan, RS diharapkan dapat memberikan pelayanan yang berkualitas. Tujuan Kesehatan dan Keselamatan Kerja Tujuan Kesehatan dan Keselamatan Kerja menurut Mangkunegara (2002), Yaitu : Agar setiap pegawai mendapat jaminan kesehatan dan keselamatan kerja baik secara fisik, sosial dan psikologis, Agar setiap perlengkapan dan peralatan kerja digunakan sebaik baiknya dan seektif mungkin, Agar semua hasil produksi dipeliharan keamanannya, Agar adanya jaminan atas pemeliharaan dan peningkatan kesehatan gizi pegawai. Potensi bahaya di RS dapat disebabkan oleh faktor, yaitu: Faktor Biologi, faktor kimia, faktor ekonomi, faktor fisik, faktor psikososial, bahaya mekanik, bahaya listrik dan limbah RS yang dapat mengancam jiwa dan kehidupan bagi para karyawan RS.

\section{Daftar Pustaka}

Hasibuan, Rahman. ( 2017). Pengaruh Kesehatan dan Keselamatan Kerja, Pelatihan dan Kerja Tim Terhadap Kinerja Tenaga Medis di Rumah Sakit Budi Kemuliaan Batam. Jurnal Dimensi, 6 (2) : 323-340.

Ivana, Azza. Dkk. (2014). Analisa Komitmen Manajemen Rumah Sakit (RS) Terhadap Keselamatan Dan Kesehatan Kerja (K3) Pada RS Prima Medika Pemalang. Jurnal Kesehatan Masyarakat (e-Journal), 2 (1) : 35-41.

Potter \& Perry. (2005). Buku Ajar Fundamental Keperawatan Konsep, Proses, dan Praktik. Edisi 4 Vol.1. Jakarta : EGC.

Purba, Hana I D, dkk. (2018) .Studi Kebijakan,Perencanaan dan Pelaksanaan Keselamatan dan Kesehatan Kerja Rumah Sakit (K3RS) di Rumah Sakit Umum (RSU) Mitra Sejati. Jurnal Mutiara Kesehatan Masyarakat, 3 (2): 113-124.

Putri, Sentya, dkk. (2018). Pelaksanaan Keselamatan dan Kesehatan Kerja Terhadap Kejadian Kecelakaan Kerja Perawat di Rumah Sakit . Jurnal Endurance 3(2) : 271-277.

Salawati, Liza, dkk. (2014). Analisi Tindakan Keselamatan dan Kesehatan Kerja Perawat Dalam Pengendalian Infeksi Nosokomial di Ruang ICU 
RSUD DR.Zainoel Abidin Banda Aceh. Jurnal Kedokteran Syiah Kuala , 14 ( 3) : 128-134 .

Simamora, R. H. (2018). Buku ajar keselamatan pasien melalui timbang terima pasien berbasis komunikasi efektif: SBAR. Medan: USU press.

Simamora, R. H. (2019). Buku ajar pelaksanaan identifikasi pasien. Uwais Inspirasi Indonesia.

Sumarni. (2017). Analisis Implementasi Patient Safety Terkait Peningkatan Mutu Pelayanan Kesehatan di Rumah Sakit. Jurnal Ners dan Kebidanan Indonesia.

Widiasari, Handayani, H., \& Novitestari, E. (2019). Kepuasan Pasien Terhadap Penerapan Keselamatan Pasien di Rumah Sakit. Jurnal Keperawatan Indonesia, $22(1), 43-46$.

Yusuf,M. (2017). Penerapan Patient Safety di Ruang Rawat Inap Rumah Sakit Umum Daerah DR.Zainoel Abidin. Jurnal Ilmu Keperawatan, 5 ( 1 ). Yvana, A., Widjasena, B., \& Jayanti, S. (2014). Analisa Komitmen Manajemen Rumah Sakit terhadap Keselamatan dan Kesehatan Kerja (K3) Pada RS Prima Medika Palembang. Jurnal Kesehatan Masyarakat, 2(1), 36-40. 